\title{
SPATIAL AND TEMPORAL DISTRIBUTION OF FISH IN PALMAS BAY, UBATUBA, BRAZIL
}

Maria Luiza Chisté Flaquer da Rocha*, Wellington Silva Fernandez and Alfredo Martins Paiva Filho

Instituto Oceanográfico da Universidade de São Paulo

Laboratório de Ecologia Reprodutiva e do Recrutamento de Organismos Marinhos

(Praça do Oceanográfico, 191, 05508-120 São Paulo, SP, Brasil)

*Corresponding Author: isaflaquer@usp.br

\begin{abstract}
A B S T R A C T
The aim of this study was to analyze the distribution and abundance of the fish fauna of Palmas bay on Anchieta Island in southeastern Brazil. Specimens were caught in the summer and winter of 1992, using an otter trawl at three locations in the bay. The specimens were caught in both the nighttime and daytime. Data on the water temperature and salinity were recorded for the characterization of the predominant water mass in the region, and sediment samples were taken for granulometric analysis. A total of 7656 specimens (79 species), with a total weight of approximately $300 \mathrm{~kg}$, were recorded. The most abundant species were Eucinostomus argenteus, Ctenosciaena gracilicirrhus, Haemulon steindachneri, Eucinostomus gula and Diapterus rhombeus, which together accounted for more than $73 \%$ of the sample. In general, the ecological indices showed no differences in the composition of species for the abiotic variables analyzed. The multivariate analysis showed that the variations in the distribution of the fish fauna were mainly associated with intra-annual differences in temperature and salinity, resulting from the presence of South Atlantic Central Water (SACW) in the area during the summer. The analysis also showed an association with the type of bottom and a lesser association with respect to the night/day periods.
\end{abstract}

\section{R ESUMO}

Este estudo teve como objetivo analisar a composição e a abundância da fauna de peixes provenientes da enseada Palmas em Ubatuba, costa sudeste do Brasil. Os espécimes foram obtidos no verão e no inverno de 1992, utilizando-se uma rede de arrasto de fundo em três locais da enseada. Os arrastos foram realizados no período noturno e no período diurno. Foram obtidos dados de temperatura e salinidade da água para caracterização da massa de água predominante na região e amostras do sedimento para análise granulométrica. Foram capturadas 79 espécies de Actinopterygii, representadas por 7656 indivíduos com peso total aproximado de $300 \mathrm{~kg}$. As espécies mais abundantes foram Eucinostomus argenteus, Ctenosciaena gracilicirrhus, Haemulon steindachneri, Eucinostomus gula e Diapterus rhombeus e representaram mais de $73 \%$ da amostra. Os índices ecológicos utilizados, de uma maneira geral, não mostraram diferenças na composição das espécies quanto às variáveis abióticas analisadas. A análise multivariada empregada mostrou que as variações encontradas na distribuição da fauna de peixes foram associadas principalmente às diferenças intraanuais de temperatura e salinidade, relacionadas à presença da Água Central do Atlântico Sul no verão na área de estudo. A análise também mostrou uma associação em relação ao tipo de fundo e uma menor associação em relação aos períodos do ciclo noite/dia.

Descriptors: Tropical fish; Temporal distribution; Multivariate analysis; Palmas bay; Brazil.

Descritores: Peixes tropicais; Distribuição temporal; Análise multivariada; Enseada das Palmas;

Brasil.

\section{INTRODUCTION}

Marine fish communities in tropical regions characteristically have a large number of species and complex interactions as compared to those of the communities in temperate regions. This is particularly true in places less than 200 meters deep. However,

$\overline{\text { Contr. No. } 884}$ do Inst. oceanogr. da Usp. changes in the biological communities are generally much smaller in tropical oceans, except when substantial seasonal changes occur in water masses in these regions (LONGHURST; PAULY, 2007).

Besides intra-annual environmental differences, short-term changes, such as those of the day/night cycle, can also affect the interactions between the distribution and abundance of these communities, such as behavioral changes in the period 
of activity to that of rest (and vice versa), competition for prey etc (NOAKES, 1992; HELFMAN, 1993; AXENROT et al., 2004). In studies of the demersal fish community, the bottom type is also clearly a fundamental factor in controlling the fish distribution: muddy, sandy or consolidated bottoms each exhibit characteristic communities of invertebrates, important food items for demersal fish (LOWE-McCONNELL, 1999).

In general, methods for the study of the distribution of fishes focus on the pattern of a single species, which hinders the understanding of the influence of environmental variables on the fish population as a whole. Since the distribution is often the result of more than one variable, a mathematical approach is advisable, to facilitate the visualization of patterns. These patterns make a better understanding of the structure of the community and corresponding relationships with the environmental variables possible (JACKSON, 1993; SCHULZ et al., 2007).

Redundancy analysis (RDA) is a method of multivariate analysis and its central purpose is to reduce the dimensions of a set of data that presents a large number of interrelated variables while retaining as much of the variation of this set as possible (CAMARGO et al., 2003). Multivariate analysis has been used for the study of fish populations by a number of authors, among them Pihl and Wennhagem (2002); Pessanha and Araújo (2003); Veja-Cendejas and Santillana (2004); Tuya et al. (2005); Azevedo et al. (2007) and Vaz et al. (2007).

Most of the information on the spatial and temporal variation in the distribution of fish populations has come from trawling and shows that the largest catches occur in regions with shallower water (LOWE-McCONNELL, 1999) and a greater number of individuals and biomass have been obtained at night (HORN, 1980; STONER, 1991; ALBERT; BERGSTAD, 1993; MICHALSEN et al., 1996) Nevertheless, these results are associated with various factors, among them the net-fleeing behavior, which can be affected by the period in which the trawl is carried out, since fish can perceive the approaching net both by vision and hearing (ENGAS, 1994). Due to the complexity of the behavioral responses of fish to the variability of the marine environment, studies that generate information on the structure of fish communities and the mechanisms that affect their distribution and abundance are important, mainly in tropical regions.

Various authors have studied the fish populations in the Ubatuba region, among them Matsuura and Nakatami (1979), Nonato et al. (1983) and Braga and Gointein (1984) surveyed the ichthyofauna in Palmas bay; Rossi-Wongtschowski and Paes (1993), Soares et al. (1993) and Rocha and Rossi-Wongtschowski (1998) classified the demersal fish species in the region into functional, structural and trophic groups, and Zahorcsak et al. (2000), who observed in loco the feeding habits of some species in the waters surrounding Anchieta Island.

Important fishing resources are concentrated on the continental shelf. Understanding the structure of fish populations is important for the management of multi-species stocks. Because of this need, the present study examines some of the environmental mechanisms involved in the spatial and temporal distribution of the ichthyofauna in Palmas bay.

\section{Materials ANd Methods}

\section{Study Area}

Palmas bay is located in the northern part of the Anchieta Island State Park, in Ubatuba, São Paulo state, southeastern Brazil $\left(23^{\circ} 32^{\prime} \mathrm{S} ; 45^{\circ} 04^{\prime} \mathrm{W}\right)$. The bay is a protected area of $2 \mathrm{~km}^{2}$, facing the mainland, with a maximum depth of $10 \mathrm{~m}$ at its entrance. It has beaches practically throughout its extension, except for rocky shorelines at its western and extreme eastern ends (Fig. 1). The sediment is mainly constituted of fine and very fine sand, with the presence of mud in some spots. The coarsest sands occur in areas near the rock formations (FUMEST, 1974).

\section{Data Collection}

The specimens were collected in the summer (February) and winter (July) of 1992, at three locations in Palmas bay: east, west and entrance. A total of 36 collections were undertaken (18 in the summer and 18 in the winter), during the night and day ( 9 collections each), using an otter trawl (12 m mouth, $30 \mathrm{~mm}$ mesh in the body and sleeves and $25 \mathrm{~mm}$ in the cod-end), towed at a speed of approximately 2 knots, with a 10minute fishing effort.

Water samples were taken at all the oceanographic stations, at the surface, middle depth and bottom, to record the salinity and temperature. Sediment samples were also obtained at the three locations using a van Veen collector. A triangular Shepard diagram (1954) was plotted to identify granulometric classes.

Specimens were frozen to death and then identified to species level; each fish was counted, and its total length $(\mathrm{mm})$ and fresh weight $(\mathrm{g})$ measured.

\section{Data Analysis}

Data were analyzed in relation to the numerical abundance and composition of species caught in the summer and winter, during the day and night and at the three locations (east, west and entrance). Dominant species were analyzed separately by plotting relative frequency distribution graphs. 


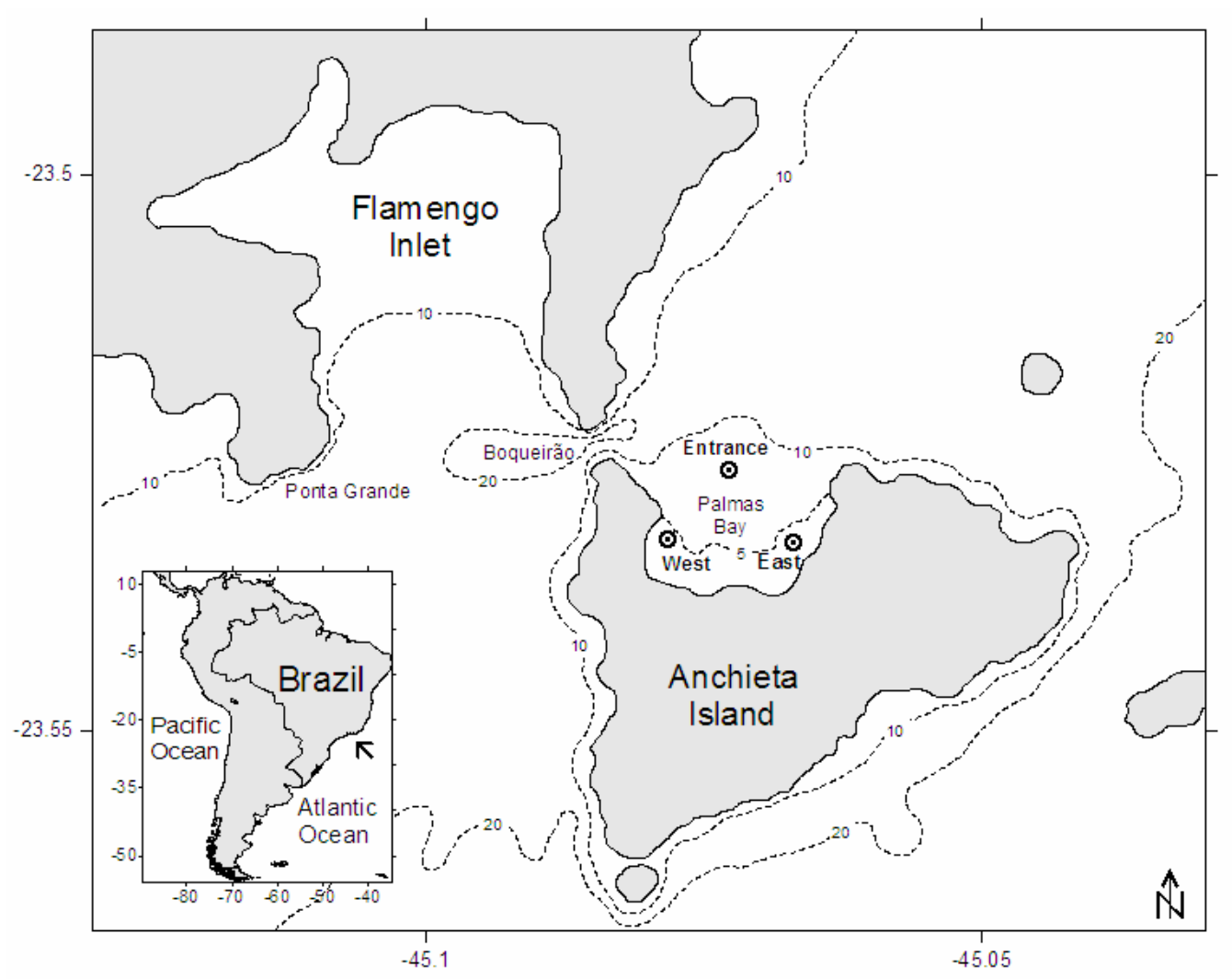

Fig. 1. Locations of the sampling sites (West / East sides and Entrance of the bay) in Palmas Bay.

Species diversity was measured considering Margalef richness (R), Simpson dominance $(\lambda)$, Simpson diversity (D), ShannonWiener diversity $\left(\mathrm{H}^{\prime}\right)$ and Pielou evenness $(\mathrm{J})$ indexes (Washington, 1984).

For the multivariate analysis, some preliminary procedures were carried out. In order to reduce the influence of less abundant species, all the species with less than $1 \%$ accumulated occurrence were excluded from the abundance matrix (SEDBERRY; CARTE, 1993; FEYRER; HEALEY, 2003). The reduced matrix data were then submitted to an $\mathrm{F}_{\max }$ test and transformed into $\operatorname{Ln}(\mathrm{x}+1)$ form, before further transformation through the Hellinger's distance (RAO, 1995; LEGENDRE; LEGENDRE, 1998).

The abiotic matrix was formed of the quantitative explanatory variables regarding season (summer and winter), period (daytime and nighttime) and locations in the bay (east. west and entrance), all of which were converted into dummy variables (Legendre and Legendre, 1998).

Redundancy analysis was used, combined with the Monte-Carlo permutation test (forward selection) to evaluate the differences in species composition and to determine the significant effect of each environmental variable on the composition of fish species (LEPS; SMILAUER, 2003).

\section{RESULTS}

Environmental Variables and Community Structure

Results from the water samples showed distinct hydrographic conditions: in the summer, the water column was stratified, with a difference in temperature between the bottom and surface of $9{ }^{\circ} \mathrm{C}$, while in the winter it was homogeneous, particularly regarding temperature (Fig. 2). Differences of temperature and salinity between summer and winter were significant $(\mathrm{p}<0.001$, ANOVA).

The results of the granulometric analysis showed that the mode was "very fine sand". In the summer, bottom conditions at the entrance differed from those of the others, presenting a smaller quantity of mud (silt + clay) and a larger quantity of coarser sand. In the winter, the west site had a fraction of coarser sand. 


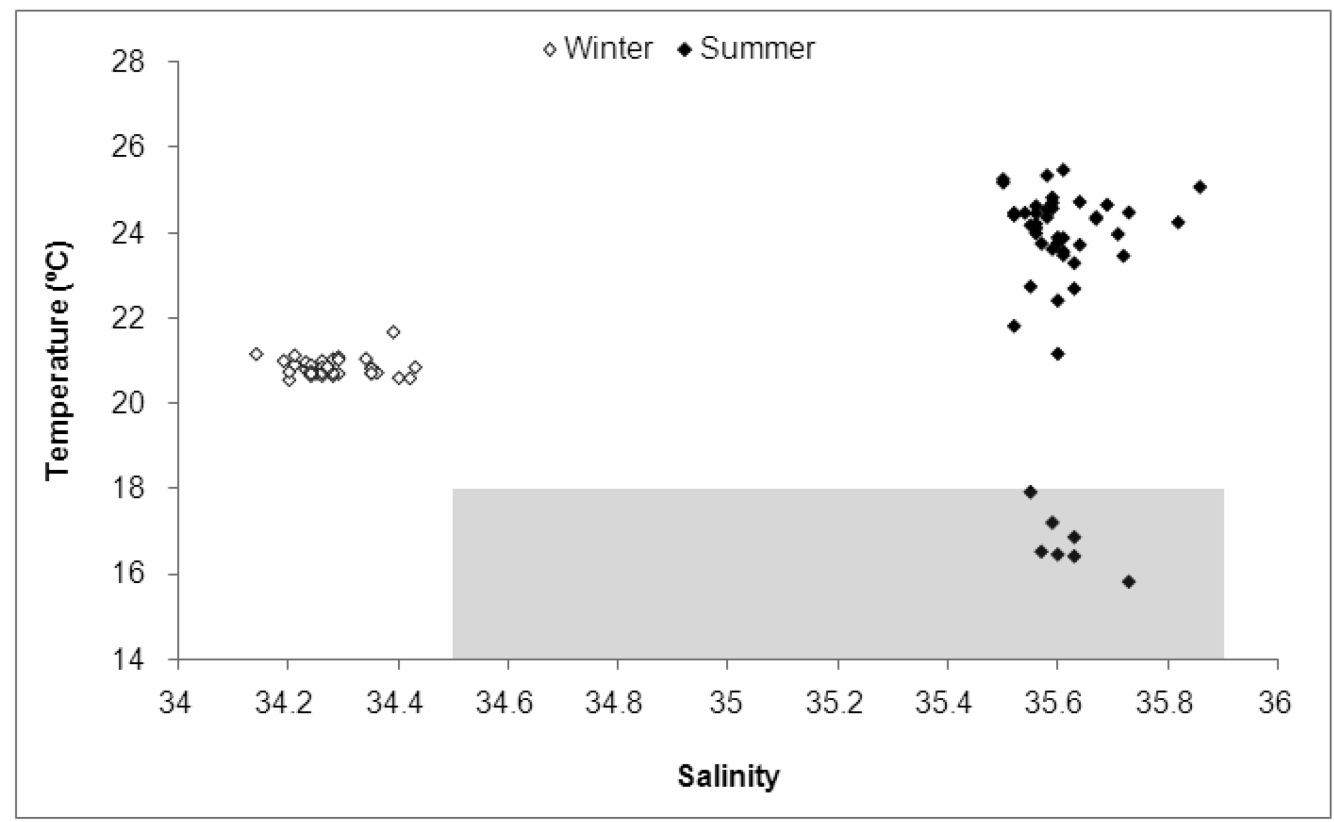

Fig. 2. Diagram T - S showing the difference between summer and winter on water column in the study region in 1992.

The ichthyofauna of Palmas bay was conformed by 7656 individuals, belonging to 79 species, 65 genera and 35 families with a total weight of $298.25 \mathrm{~kg}$ (Table 1). Of the total individuals, $54.51 \%$ were caught in the summer and $45.49 \%$ in the winter. The highest numerical abundance was recorded at night with 4029 individuals $(162.87 \mathrm{~kg})$ more than in the daytime with $3627(135.48 \mathrm{~kg})$. With respect to spatial distribution, the largest numerical abundance was in the west, with 3082 individuals, while the respective figures for the entrance and east were 2597 and 1977 specimens.

Eucinostomus argenteus, Ctenosciaena gracilicirrhus, Haemulon steindachneri, Eucinostomus gula and Diapterus rhombeus were the most abundant species, accounting for $73 \%$ of the sample.

$E$. argenteus and $H$. steindachneri were the only two species that appeared among the top five at all the locations. However, $C$. gracilicirrhus was the most abundant species at the entrance, followed by $E$. argenteus at the west site and $H$. steindachneri with homogenous distribution at all three locations. The sum of the five most abundant species at the east site was $67 \%$, while in the west it was $81 \%$ and at the bay entrance $76 \%$ (Fig. 3).

Regarding the period of the day, $C$. gracilicirrhus was the most abundant species in the daytime and E. argenteus at night. The total of the relative abundances of the five most common species in the two periods was relatively similar, with $76 \%$ during the daytime and $73 \%$ in the nighttime (Fig. 4).

Within a seasonal perspective, the five most abundant species in the summer and winter were the same as found in the total sample, representing $75 \%$ and $72 \%$ of the fish caught, respectively (Fig. 5). However, the relative abundance of these species differed, with $C$. gracilicirrhus being most abundant in the summer and E. argenteus in the winter.

\section{Ecological Index}

The results of the diversity measures are shown in Table 2. There was no large variation between summer and winter as regards the number of species, and in the other indices, only the summer differed with a greater number of individuals. Regarding the capture period, there was a tendency for higher values during the daytime, with the exception of the Simpson dominance index. Among the three locations, the west site had the greatest number of species, highest number of individuals, greatest richness and Simpson dominance, but the lowest values of the other indices.

\section{Multivariate Analysis}

The abundance matrix, which was originally represented by 79 species, was reduced to 46 species after excluding the rare ones, in accordance with the above-mentioned criterion. 
Table 1. List of the 79 fish species in Palmas bay, 1992. The 46 most abundant species included in the analysis, which contributed to $>1 \%$ of total fish number data in bold. Families have been ordered in accordance with Menezes et al. (2003). $\mathrm{Ni}=$ number of individuals. Keys to the species name are specified.

\begin{tabular}{l}
\hline Specie - Code (Ni) \\
\hline ALBULIDAE \\
Albula vulpes - Alvu (2) \\
\hline MURAENIDAE
\end{tabular}

PRIACANTHIDAE

Priacanthus arenatus - Prar (33)

Umbrina coroides - Umco (5)

POMATOMIDAE

MULLIDAE

MURAENIDAE

Pomatomus saltatrix - Posa (2)

Gymnothorax ocellatus - Gyoc (41)

CARANGIDAE

Mullus argentinae - Muar (12)

OPHICHTHIDAE

CARANGIDAE

Ophichthus gomesii - Opgo (1)

ENGRAULIDAE

Decapterus punctatus - Depu (1)

Anchoa lyolepis - Anly (6)

Selene setapinnis - Sese (86)

Anchoa lyolepis - Anly (6)
Anchoa tricolor - Antr (5)

Anchoviella lepidentostole - Anle (2)

Lycengraulis grossidens - Lygr (2)

PRISTIGASTERIDAE

Selene vomer - Sevo (5)

Trachinotus carolinus - Trca (1)

LUTJANIDAE

Lutjanus analis - Luan (5)

Chirocentrodon bleekerianus - Chbl (106)

Lutjanus synagris - Lusy (7)

Pellona harroweri - Peha (194)

GERREIDAE

CLUPEIDAE

Diapterus rhombeus - Dirh (308)

Harengula clupeola - $\mathrm{Hacl}(3)$

Sardinella brasiliensis - Sabr (4)

SYNODONTIDAE

Eucinostomus argenteus - Euar (2085)

Eucinostomus gula - Eugu (440)

Eucinostomus melanopterus - Eume (16)

Synodus foetens - Syfo (15)

Trachynocephalus myops - Trmy (6)

OPHIDIIDAE

Ophidion holbrooki - Opho (1)

OGCOCEPHALIDAE

\section{HAEMULIDAE}

Anisotremus virginicus - Anvi (1)

Conodon nobilis - Cono (1)

maculatus - Psma (16)

CHAETODONTIDAE

Chaetodon striatus - Chst (2)

BLENNIIDAE

Parablennius pilicornis - Papi (1)

GOBIIDAE

Microgobius meek - Mime (1)

SPHYRAENIDAE

Sphyraena guachancho - Spgu (2) TRICHIURIDAE

Trichiurus lepturus - Trle (5)

STROMATEIDAE

Peprilus paru - Pepa (1) BOTHIDAE

Ogcocephalus vespertilio - Ogve (4)

MUGILIDAE

Haemulon aurolineatum - Haau (3)

Haemulon steindachneri - Hast (955)

Orthopristis ruber - Orru (232)

Bothus ocellatus - Booc (39)

Bothus robinsi - Boro (5)

PARALICHTHYIDAE

Citharichthys macrops - Cima (1)

Citharichthys spilopterus - Cisp (30)

Cyclopsetta chittendeni - Cych (3)

Etropus crossotus - Etcr (64)

Pomadasys corvinaeformis - Poco (40) Etropus longimanus - Etlo (20)

SPARIDAE

Etropus longimanus - Etlo
Paralichthys $s p$ - Pasp (1)

Paralichthys $s p$ - Pasp (1)
Syacium micrurum - Symi (22)

Calamus penna - Cape (5)

DACTYLOPTERIDAE

Dactylopterus volitans - Davo (22)

\section{SCIAENIDAE}

SCORPAENIDAE
Scorpaena brasiliensis - Scbr (3)

Scorpaena isthmensis - Scis (1)

TRIGLIDAE

Ctenosciaena gracilicirrhus - Ctgr (1830)

Cynoscion jamaicensis - Cyja (46)

Isopisthus parvipinnis - Ispa (9)

Prionotus punctatus - Prpu (214)

Larimus breviceps - Labr (19)

Menticirrhus americanus - Meam (25)

Micropogonias furnieri - Mifu (115)

Odontoscion dentex - Odde (2)

Diplectrum formosum - Difo (130)

Diplectrum radiale - Dira (41)

Epinephelus morio - Epmo (1)

Epinephelus niveatus - Epni (3)

Paralonchurus brasiliensis - Pabr (130)

Syacium papillosum - Sypa (107)

CYNOGLOSSIDAE

Symphurus tesselatus - Syte (29)

Symphurus trewavasae - Sytr (2)

MONACANTHIDAE

Stephanolepis hispidus - Sthi (1)

TETRAODONTIDAE

Sphoeroides tyleri - Spty (5)

DIODONTIDAE

Cyclichthys spinosus - Cysp (1)

Stellifer rastrifer - Stra (1)

79 species $/ 35$ families $\quad \mathrm{Ni}=7656$

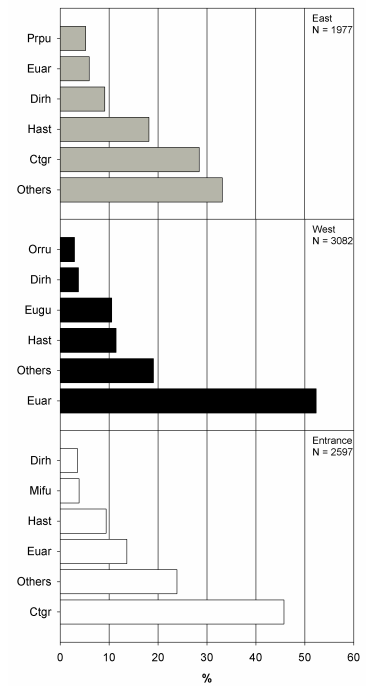

Fig. 3. Relative abundance of fish species that make a greater contribution to differences between localities in Palmas Bay. Ctgr $=$ Ctenosciaena gracilicirrhus; Dirh $=$ Diapterus rhombeus; Euar = Eucinostomus argenteus; Eugu = Eucinostomus gula $;$ Hast $=$ Haemulon steindachneri $;$ Mifu $=$ Micropogonias furnieri; Orru $=$ Orthopristis ruber and Prpu $=$ Prionotus punctatus. 


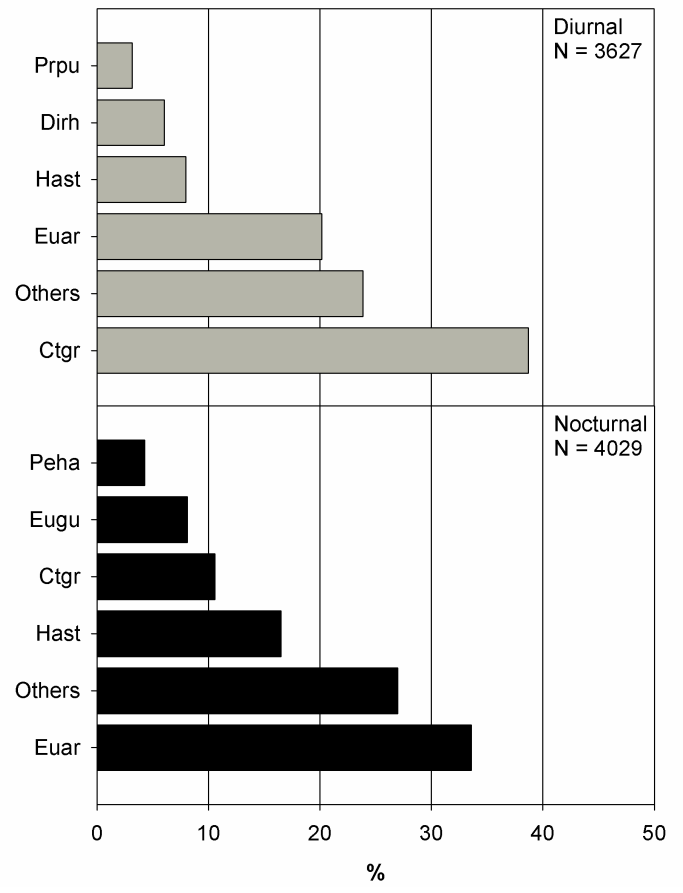

Fig. 4. Relative abundance of fish species that make a greater contribution to the differences between periods of the day in Palmas Bay. Ctgr = Ctenosciaena gracilicirrhus; Dirh = Diapterus rhombeus; Euar = Eucinostomus argenteus; Eugu = Eucinostomus gula $;$ Hast $=$ Haemulon steindachneri $;$ Peha $=$ Pellona harroweri and Prpu = Prionotus punctatu .

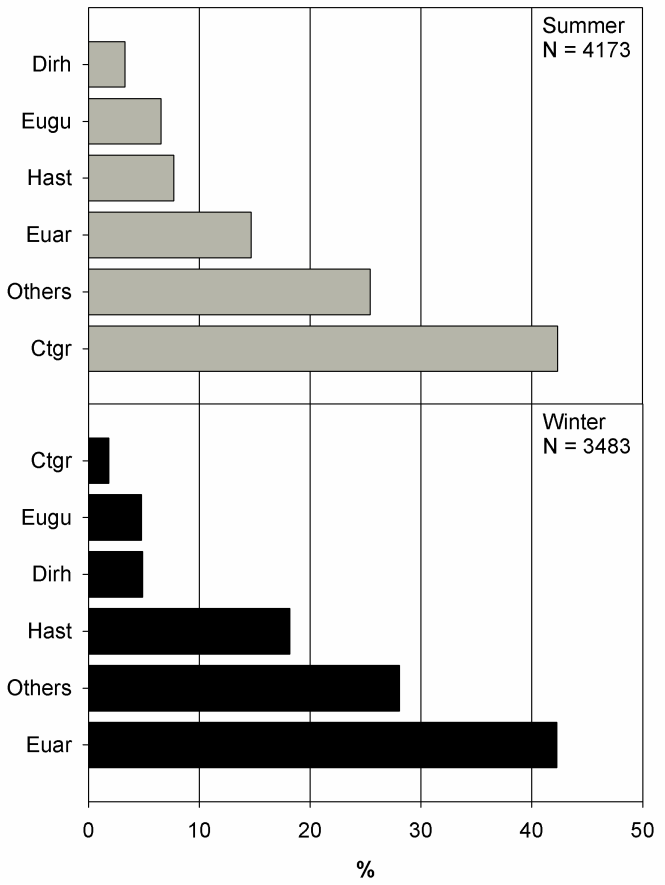

Fig. 5. Relative abundance of fish species that make a greater contribution to the differences between seasons of the year in Palmas Bay. Ctgr = Ctenosciaena gracilicirrhus; Dirh = Diapterus rhombeus; Euar = Eucinostomus argenteus; Eugu = Eucinostomus gula and Hast = Haemulon steindachneri

Table 2. Ecological indexes of total catches by season of the year, day/night periods and sample sites. $\mathrm{S}=$ number of species; $\mathrm{Ni}=$ number of individuals; Indexes: $\mathrm{R}=$ Richness of Margalef; $\mathrm{J}=$ Equitability of Pielou; $\mathrm{H}^{\prime}=$ Diversity of Shannon; $\lambda=$ Dominance of Simpson and D = Diversity of Simpson.

\begin{tabular}{lccccccc} 
& $\mathbf{S}$ & $\mathbf{N i}$ & $\mathbf{R}$ & $\mathbf{J}$ & $\mathbf{H}^{\prime}$ & $\boldsymbol{\Lambda}$ & $\mathbf{D}$ \\
\hline Summer & 61 & 4173 & 7.197 & 0.555 & 2.279 & 0.216 & 0.784 \\
Winter & 60 & 3483 & 7.234 & 0.550 & 2.253 & 0.222 & 0.778 \\
Diurnal & 67 & 4029 & 7.951 & 0.580 & 2.437 & 0.164 & 0.836 \\
Nocturnal & 61 & 3627 & 7.321 & 0.560 & 2.303 & 0.205 & 0.796 \\
East & 52 & 1977 & 6.720 & 0.654 & 2.584 & 0.135 & 0.865 \\
Entrance & 50 & 2597 & 6.232 & 0.554 & 2.168 & 0.243 & 0.757 \\
West & 55 & 3082 & 6.722 & 0.489 & 1.958 & 0.302 & 0.698 \\
\hline
\end{tabular}


The results obtained by RDA presented an explanation of the distribution of the fish community in Palmas bay as a function of $53.7 \%$ of the environmental variables. Site, season and period of the day explained $25.1 \%, 18.7 \%$ and $9.9 \%$, respectively (Fig. 6). For the independent variables, the strongest correlations to the set of data occurred at the west site $(\mathrm{F}=3.350 ; \mathrm{p}=0.0015)$, summer and winter $(\mathrm{F}=$ $2.993 ; \mathrm{p}=0.0014)$ and the day and night periods $(\mathrm{F}$ 1.704; $p=0.0482$ ). The east and entrance sites did not present any significant correlation to the abundance matrix $(\mathrm{p}>0.05)$.

The analysis of the statistical significance of the relationship between the species and environmental variables (t-value plot) revealed sets of species that had similar distribution patterns associated with the environmental variables in Palmas bay (Fig. 7), forming five sets of species. The groups were classified according to the most significant environmental variable, as follows:

a. "Seasonal Group" - whose distribution was mainly associated with the summer and winter, regardless of its location in the bay, composed of nine species: Haemulon steindachneri, Anchoa lyoleps, Chloroscombrus chrysurus, Cynoscion jamaicensis, Diplectrum formosum, Lutjanus synagris, Mullus argentinae, Sphoeroides tyleri and Syacium micrurum; b. "Site Group" - whose distribution was mainly associated with their location, consisting of twelve species: Calamus Penna, Chirocentrodon bleekerianus, Citharichthys spilopterus, Diplectrum radiale, Diplodus argenteus, Etropus crossotus, Etropus longimanus, Gymnothorax ocellatus, Micropogonias furnieri, Pellona harroweri, Prionotus punctatus and Symphurus tesselatus;

c. "Seasonal/Site Group" - whose distribution was associated with both the location and the season, constituted by eight species: Ctenosciaena gracilicirrhus, Eucinostomus argenteus, Larimus breviceps, Menticirrhus americanus, Paralonchurus brasiliensis, Priacanthus arenatus, Pseudupeneus maculatus and Trachynocephalus myops;

d. "Period/Site Group" - associated with the location and day/night period, formed of a single species: Bothus ocellatus, and

e. "No Association Group", included sixteen species whose distribution had no relation to any of the environmental variables considered in this study: Anchoa tricolor, Bothus robinsi, Dactylopterus volitans, Diapterus rhombeus, Eucinostomus gula, Eucinostomus melanopterus, Isopisthus parvipinnis, Lutjanus analis, Orthopristis ruber, Pomadasys corvinaeformis, Selene setapinnis, Selene vomer, Synodus foetens, Syacium papillosum, Trichiurus lepturus and Umbrina coroides.

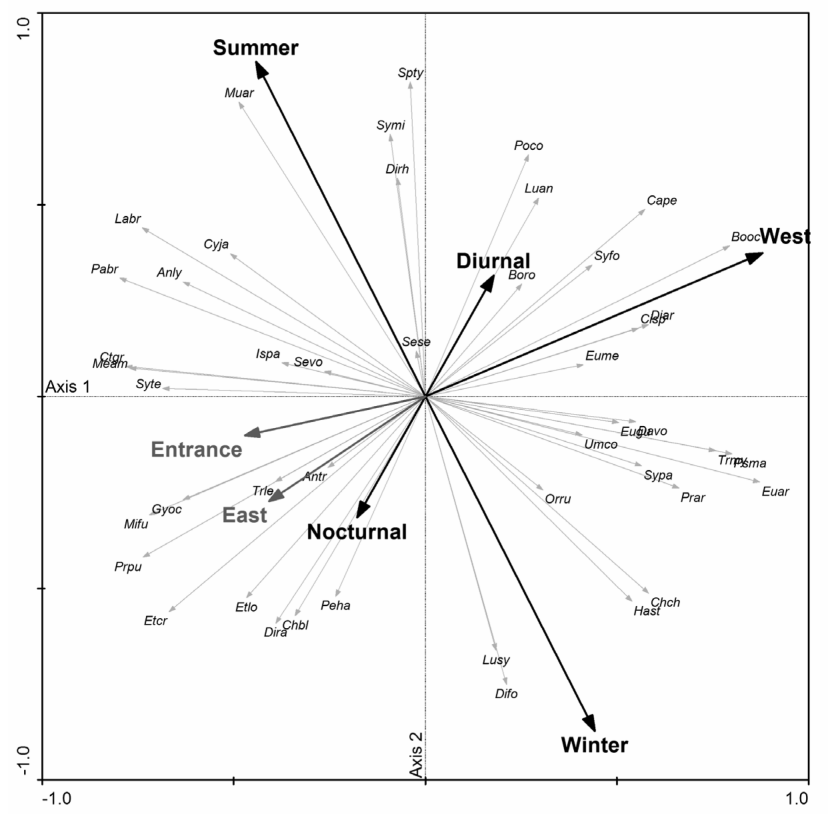

Fig. 6. Plot of ordination diagram on the first two RDA axes of 46 species captured in Palmas Bay and position on ordination axes of three explanatory variables (retained from RDA with forward selection and associated MonteCarlo permutation test) that add significantly $(\mathrm{P}<0.05)$ to the explanation of the species variation. 


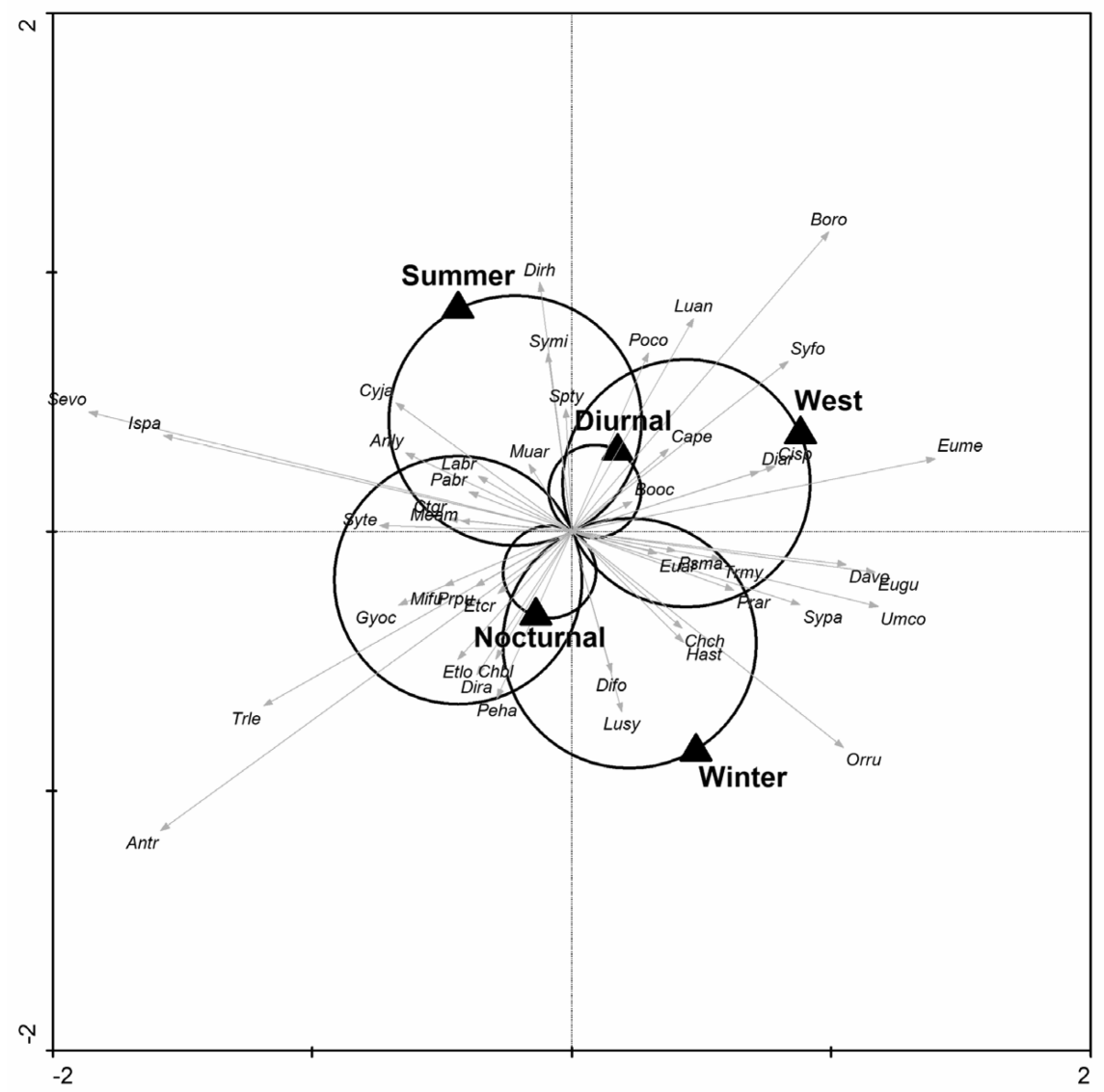

Fig. 7. Plot of t-value of the first two RDA axes of 46 species captured in Palmas Bay, using the reduced matrix of abundance and the dummy matrix of environmental variables. Species keys are specified in Table 1.

\section{Discussion}

Information on the ecology of tropical marine fishes, especially demersal species, comes mainly from bottom trawling over sand and firm mud. However, achieving a more complete understanding of the organization of fish communities is a complex task, since many factors may influence their temporal and spatial distribution. The results of the present study showed a distribution pattern of the fish species in relation to some oceanographic parameters, particularly the intra-annual variations with respect to temperature and salinity and the type of bottom. $C$. gracilicirrhus, E. argenteus and $H$. steindachneri were the species considered dominant in this study and their presence was strongly associated with the seasonal dynamic of the water masses in the region.

The dynamic of the water masses over the continental shelf in southeastern Brazil has been studied by Matsuura (1986) and Castro Filho et al.,
(1987), who describe patterns of greater intensity and occupation of the area by water masses. The inner continental shelf in the region in the summer is occupied by Coastal Water (CW), which has low salinity and high temperature, at the surface layer, while the bottom layer is penetrated by South Atlantic Central Water (SACW), with higher salinity and lower temperature. The most marked hydrographic feature is the stratification of the water column. In the winter, the SACW is registered with greater frequency beyond the 50-meter isobath, making the water column near the coast homogenous.

This cool bottom water (SACW) is responsible for increasing the new local primary production (AIDAR-ARAGÃO et al., 1993), altering the trophic structure, which also changes with the entrance of species from the middle and outer continental shelf or with the spawning of fish and permanence of larvae that find favorable conditions to feed (MATSUURA; NAKATANI, 1979). The water mass dynamic is also a factor that determines the 
structure of the benthic macrofauna, which plays a fundamental role both as a receiver of energy from the pelagic system and as a supplier of energy to demersal organisms (PIRES-VANIN, 1993). An important conditioning factor in the study of fish distribution is the depth at which trawls are performed. However, this parameter has not been taken into consideration here because the depths were practically constant at all three locations. Another important factor controlling distribution is the nature of the bottom deposits. In this study, the west, east and entrance sites of Palmas bay presented different sediment fractions, which may indicate different types of associated fauna which, in turn, affects the presence or absence of different fish species.

The Sciaenidae family is considered the most important along the southeastern coast of Brazil in terms of structure of ecosystems, and $C$. gracilicirrhus is one of the main species in the Ubatuba region (ROCHA; ROSSIWONGTSCHOWSKI, 1998; MUTO et al., 2000). In the present study, the specimens captured were predominantly juveniles, with average length of 96.55 $\mathrm{mm}$ (s.d. = 13.22). These juveniles probably use the area to feed during the summer and then spread to deeper water at other times of the year. The same results were found by Araújo (2006) at Sepetiba bay (Rio de Janeiro state, Brazil). This explains the lesser abundance of this species in the sample collected in winter in Palmas bay.

This species is classified here in the Seasonal/Site Group because it occurred almost exclusively in winter at the bay entrance. Even though the study region has a much smaller and shallower area, the markedly seasonal occurrence of $C$. gracilicirrhus corroborates the studies of RossiWongtschowski and Paes (1993), who found a movement of this species from deeper waters to closer in-shore areas in the Ubatuba region, with the arrival of SACW in the summer, thus leading to the classification of this species as seasonal. However, Rocha and Rossi-Wongtschowisk (1998) classified this species as belonging to the group of tropical sciaenids, which are associated with warm water in this region. Muto et al., (2000) found that $C$. gracilicirrhus was one of the dominant species of the inner continental shelf of the São Sebastião region, to the south of Ubatuba, in the summer, and also found an association of this species with warmer and shallower water.

These results might indicate not the entrance of the species with the arrival of SACW, but rather a greater population density in the region as a way of remaining in the warmer water closer to the shoreline at times when cooler water reaches the inner shelf. This seasonal movement was also observed by Araújo and Azevedo (2001), who classified the species as belonging to the group that occurs in coastal waters of the continental shelf at depths between 15 and $100 \mathrm{~m}$, over sandy and muddy sediments, and whose distribution is mainly determined by temperature, salinity and depth. There is no information available on the diel variation of capture.

The other dominant species, E. argenteus (Gerreidae), has also been classified in the Seasonal/Site Group, as its winter abundance is twice that of the summer. The same result was obtained by Rossi-Wongtschowski and Paes (1993) and Rocha and Rossi-Wongtschowski (1998), who classified the species as seasonal, more common in winter on the inner continental shelf in the Ubatuba region. Matheson and Gilmore (1995) also found, in their studies of the southeastern seaboard of the United States, that the occurrence of this species was markedly seasonal, as the juveniles there penetrated into the estuary at the end of summer, while the adults remained mainly over the shelf. Weinstein et al. (1980) classified E. argenteus as having an intermediate behavior pattern between the insular and continental groups in an estuary in North Carolina (USA). In this study, the seasonal variation in the occurrence of this species might be related to the relatively accentuated changes in salinity (roughly 1.4) between summer and winter, since other studies found that the presence of E. argenteus was related to the higher salinity in Términos Lagoon in Mexico (AGUIRRE-LEÓN; YÁÑEZ-ARANCIBIA, 1986; WEINSTEIN et al., 1980). Another study observed an increase in the feeding activity in periods of high salinity in a lagunar system in the Columbian Caribbean (ARENAS-GRANADOS; ACERO, 1992). Araújo et al. (2002) found that the salinity had a greater influence in species composition than temperature in Sepetiba bay (Rio de Janeiro state, Brazil). According to these authors, the relatively stable hydrological conditions create a well-defined salinity gradient, which may limit the spatial distribution of some species physiologically.

In Palmas bay the average length of $E$. argenteus specimens during winter was $92 \mathrm{~mm}$ (s.d. = 28.74), which relates mainly to juveniles. In the summer the average length was $122 \mathrm{~mm}$ (s.d. = 23.47), but with a lower abundance. This length indicates the beginning of gonadal maturation for this species in Términos Lagoon, Mexico (AGUIRRE-LEÓN; YÁÑEZ-ARANCIBIA, 1986). A hypothesis regarding the presence of adults in this season is found in the studies of Matsuura and Nakatani (1979) on Palmas bay, where it was found that Gerreidae larvae were very abundant all year round, but particularly in the summer. According to the authors, this is the season when spawning occurs most intensely, because the environmental conditions are most propitious for reproduction. 
E. argenteus, as well as other Gerreidae, are omnivores and daytime feeders (KERSCHNER et al., 1985; AGUIRRE-LEÓN; YÁÑEZ-ARANCIBIA, 1986; CASTILLO-RIVERA, 2005). However, their occurrence in the present study was greater at night, both in the summer and winter, meaning that their capture did not reflect the period of greatest feeding activity. It is a coastal species, typically found in shallow waters over sandy bottoms (FROESE; PAULY, 2008), which explains their high abundance in the region, principally in the western location in the bay, which presented a greater portion of coarser sand. Muto et al. (2000), in their studies in the region of São Sebastião, to the south of Ubatuba, found that the presence of $E$. argenteus and $H$. steindachneri was closely associated, in an ordination diagram, with sediment composed of coarse and very coarse sands. There are rocky shores at both ends of Palmas bay (the east and west locations) and it is natural for species more closely associated with larger grained sediment to have occurred at those two points. Variations in the sediment fractions among sites were related to the position of the trawls as regards tide and local winds, and suggest a patchy distribution pattern in Palmas bay.

H. steindachneri, another dominant species, was very frequent and abundant at all three locations, although its occurrence was not common in a previous study in the Anchieta Island region (BRAGA; GOITEIN, 1984). The Haemulidae family is associated with coral reefs and rocky areas with bottoms of sand containing shell fragments (FROESE; PAULY, 2008). This may explain its greater abundance at the west and east points and lesser abundance at the entrance of the bay. RodriguezRomero et al. (1994) also found that $H$. steindachneri was a dominant species in Concepcion bay, Mexico, and together with other species, moved along the coast over sandy substrates, though showing a certain preference for rocky areas for feeding, refuge, etc. The species has been classified here in the Seasonal Group because it is twice as abundant in the winter as in the summer, and is not associated with the location, since its occurrence in the bay was relatively homogeneous. Muto et al. (2000) found an association of $H$. steindachneri with the Coastal Water, in the shallow waters of São Sebastião.

According to Martha-Estrada (1986), the feeding habit of the genus Haemulon vary during its life cycle. H. steindachneri juveniles $(<80 \mathrm{~mm})$ feed on plankton in the daytime, while adults $(>80 \mathrm{~mm})$ have mixed nocturnal feeding habits. The average length of the specimens in the present study was 186 $\mathrm{mm}$ (s.d. = 22.21) in the summer and $189 \mathrm{~mm}$ (s.d. = 23.03) in the winter, and there was also little variation in length between the fish caught in the daytime and those caught at night. Since the smallest fish caught measured $107 \mathrm{~mm}$, the population sampled consisted mainly of adults. The fact that nearly $60 \%$ of the total trawls were carried out near the shoreline and $50 \%$ occurred at night probably determined the numerous presence of this species, which alone accounted for one-third by weight of all the fish captured. This greater abundance at night was probably due to the fact that the grunts congregate in schools during this period (SOGARD, et al., 1989; HELFMAN, 1993; LOWE-McCONNELL, 1999).

The results for the distribution and abundance of fish fauna in relation to the daytime/nighttime periods did not show a strong mutual association. The most abundant species were present among the fish caught both in the day and night periods, indicating that the time of collection does not greatly influence their aggregation in these periods and explaining the absence of these species in the Period/Site Group. However, the number of individuals and biomass were greater at night. Although variations in the abundance of fish in the daytime and nighttime can be attributed to net-fleeing behavior, which depends on the light level (ENGAS, 1994), these changes can also be related to the distribution patterns between the periods of activity and inactivity of the species, which in turn are directly related to the activity patterns of their prey (HELFMAN, 1993).

The majority of fish species in tropical and temperate regions feed primarily either in the daytime or at night, and a small number during the twilight hours (HELFMAN, 1993). The selective advantage of a temporal organization among species appears not only to consist of a reduction of competition for food resources, but also for space (LOWE-McCONNELL, 1999). Within a short period of time fish can change their behavior drastically, and allied with this is the fact that a species can use the same space as other species, but at different times of the day (NOAKES, 1992).

The fact that a species is caught in a trawl net in a certain period does not necessarily reflect its active period. It simply means the species is available, whether because it is feeding or at rest, but in the path of the fishing net. In the present study, the rarest species occurred either exclusively in the daytime or nighttime, while the majority of most abundant species were common in both these periods. The reason is that both the locations and the water column were very restricted, although it was possible to classify the species into groups according to their occurrence. In summary, in this study the greater the abundance of a species at a specific site, the less variable it was, thus explaining the weak association of the day/night periods with the distribution of the fish analyzed, since the rarest species were excluded. 
Diversity measures did not reveal a seasonal pattern for the ichthyofauna of Palmas bay, but there was a small fluctuation in the diversity indices during the 24-hour cycle, with higher values in the daytime. Gaelzer (2008), studying the region of Cabo Frio, Rio de Janeiro state (Brazil), observed that different richness and diversity values between the day and night periods can be caused by the fact that some species seek other areas to feed in or move to for protection during periods of darkness. The author also founded that the west site is the most complex of the three, where two of the dominant species occurred with greater frequency. This result may be related to the fact that collection of the samples was undertaken near the shore at this site, which is a more heterogeneous environment in structural terms, providing greater shelter and thus probably more variability of associated fauna, attracting more fish.

It should be noted that no sampling operation shows equal selectivity for all species and size groups within an area. The number, species and size of the specimens depends on their abundance in the area and the place sampled by the trawl, as well as the performance of the net and the swimming ability and sizes of the various species found (ENGAS, 1994).

The general structure of the fish fauna sampled in Palmas bay, in a very shallow, small area, showed a pattern such as would be expected for tropical inner continental shelf and coastal regions, with great species richness, few abundant or dominant species and a large number of rare species. No great variations were observed in the diversity measures for the environmental variables. Among the dominant species, E. argenteus and C. gracilicirrhus showed a seasonal/location occurrence pattern, leading to a closer association between the distribution and abundance, seasonal variation and sampling site, while H. steindachneri showed a seasonal character, but with no relationship with the sampling site in the bay.

The species considered dominant showed no pattern as regards temporal organization in the day/night periods. These results suggest that the local dynamic of the water masses is a determining variable in the distribution and abundance of the more numerous fish species in Palmas bay.

\section{ACKNOWLEDGEMENTS}

We wish to thank Dr. Patrícia Teresa Monteiro Cunningham for the data provided, Dr. Eduardo Tavares Paes for his encouragement and suggestions, Dr. June Ferraz Dias for her criticisms and suggestions, and the staff of the ECOPEX Laboratory for helping with the fieldwork, as well as the University of São Paulo's Oceanographic Institute for the use of its facilities and CAPES for the master's scholarship grant.

\section{REFERENCES}

AIDAR-ARAGÃO, E; GAETA, S. A; GIANESELLAGALVÃO, S. M. F.; KUTNER, M. B. B.; TEIXEIRA, C. Ecossistema costeiro subtropical: nutrientes dissolvidos, fitoplâncton e clorofila-a e suas relações com as condições oceanográficas na região de Ubatuba, SP. Publção esp. esp. Inst. oceanogr., v.10, p. 9-43, 1993.

AGUIRRE-LEÓN, A.; YÁÑEZ-ARANCIBIA, A. Las mojarras de la Laguna de Términos: taxonomía, biología, ecología y dinámica trófica (Pises: Gerreidae). An. Inst. Cienc. Mar Limnol., Univ. nac. Autón.Méx., , v. 13, p. 369-444, 1986

ALBERT, O. T.; BERGSTAD, O. A. Temporal and spatial variation in the species composition of trawl sample from a demersal fish community. J. Fish Biol., v. 43, p. 209-222, 1993.

ARAÚJO, F. G.; AZEVEDO, M. C. C. Assemblages of Southeast-South Brazilian Coastal Systems based on the distribution of fishes. Estuar. coast. Shelf. Sci., v. 52, p.729-738, 2001.

ARAÚJO, F. G.; AZEVEDO, M. C. C.; SILVA, M. A.; PESSANHA, A. L. M.; GOMES, I. D.; CRUZ-FILHO, A. G. Environmental influences on the demersal fish assemblages in the Sepetiba Bay, Brazil. Estuaries, v. 25, p. 441-450, 2002.

ARAÚJO, F. G.; GUIMARÃES, F. J. C.; COSTA, M. R. Environmental influences on distribution of four Sciaenidade species (Actinopterygii, Perciformes) in a tropical bay at Southeastern Brasil. Rev. Bras. Zool., v. 23, n. 2, p. 497-508, 2006

ARENAS-GRANADOS, P.; ACERO, A. Organización trófica de las mojarras (Pises: Gerreidae) de la Ciénaga Grande de Santa Marta (Caribe Colombiano). Rev. Biol. trop., v. 40, p. 287-302, 1992.

AXENROT, T.; DIDRIKAS, T.; DANIELSSON, C.; HANSSON, S. Diel patterns in pelagic fish behaviour and distribution observed from a stationary, bottommounted, and upward-facing transducer. ICES J. mar. Sci., v. 61, p. 1100-1104, 2004.

AZEVEDO, M. C. C.; ARAÚJO, F. G.; CRUZ-FILHO, A. G.; PESSANHA, A.L.M.; GUEDES, A.P.P. Demersal fishes in a tropical bay in southeastern Brazil: Partitioning the spatial, temporal and environmental components of ecological variation. Estuar. coast. Shelf. Sci., v. 75, p. 468-480, 2007.

BRAGA, F. M. S.; GOITEIN, R. Lista prévia das espécies de peixes demersais na região da ilha Anchieta (Lat.233's - Long. $45^{\circ} 05^{\top} \mathrm{W}$ ), Ubatuba, litoral norte do estado de São Paulo, Brasil. Naturália, v. 9, p. 61 - 72, 1984

CAMARGO, A. J.; HONÓRIO, K. M.; MERCADANTE, R.; MOLFETTA, F. A.; ALVES, C. N.; SILVA, A. B. F. A Study of Neolignan Compounds with Biological Activity Against Paracoccidioides brasiliensis by Using Quantum Chemical and Chemometric Methods. J. Braz. chem. Soc., v. 14, p. 809-814, 2003 
CASTILLO-RIVERA, M.; MONTIEL, M.; SANVICENTE A. L.; ZÁRATE, R. Spatial, seasonal and diel distribution patterns of two species of mojarras (Pisces:Gerreidae) in a Mexican tropical coastal lagoon. J. appl. Ichthyol., v. 21, p. 498-503, 2005

CASTRO FILHO, B. M.; MIRANDA, L. B.; MIYAO, S. Y. Condições hidrográficas na plataforma continental ao largo de Ubatuba: variações sazonais e em média escala. Bolm. Inst. oceanogr., S Paulo, v. 35, p. 135-151, 1987

ENGAS, A. The effects of trawl performance and fish behavior on the catching efficiency of demersal sampling trawls. In: FERNO, A.; OLSEN, S. (Ed.). Marine fish behaviour. Cambridge: Blackwell Scientific Publications, 1994. p. 45-68

FEYRER, F.; HEALEY, M.P. Fish community structure and environmental correlates in the highly altered southern Sacramento-San Joaquin Delta. Environ. Biol. Fishes, v. 66, p. 123-132, 2003

FROESE, R.; PAULY, D. (Ed.). FishBase. World Wide Web electronic publication. Available: <http:/www.fishbase.org>. Accessed 20 Sept. 2008

FUMEST. Fomento de urbanização e melhoria das estâncias (SP). Ilha Anchieta / plano geral de exploração turística. São Paulo: Secretaria de Esportes e Turismos do Governo do Estado de São Paulo, 1974. $69 \mathrm{p}$.

GAELZER, L. R.; ZALMON, I. R. Diel variation of fish community in sandy beaches of southeastern Brazil. Brazil. Braz. J. Oceanogr., v. 56, p. 23-39, 2008.

HELFMAN, G. S. Fish behaviour by day, night and twilight. In: PITCHER, T. J. (Ed.). Behaviour of teleost fishes. 2nd ed. London: Chapman and Hall, 1993. 715 p.

HORN, M. H. Diel and seasonal variation in abundance and diversity of shallow-water fish populations in Morro Bay, California. Fish. Bull., v. 78, p. 759 - 770, 1980.

JACKSON, D. A. Multivariate analysis of benthic invertebrate communities: the implication of choosing particular data standardizations, measures of association, and ordination methods. Hydrobiologia, v. 268, p. 9 26, 1993.

KERSCHNER, B. A.; PETERSON, M. S.; GILMORE JUNIOR, R. G. Ecotopic and ontogenic trophic variation in mojarras (Pisces: Gerreidae). Estuaries, v. 8, p. 311322, 1985

LEGENDRE, P; LEGENDRE, L. Numerical ecology. 2nd English ed. Amsterdam: Elsevier Science, 1998. 853p.

LEPS, J.; SMILAUER, P. Multivariate analysis of ecological data using CANOCO. Cambridge, UK: Cambridge University Press, 2003. 269 p.

LONGHURST, A. R; PAULY, D. Ecologia dos oceanos tropicais. São Paulo: EDUSP, 2007. $419 \mathrm{p}$

LOWE-McCONNELL, R. H. Estudos ecológicos de comunidades de peixes tropicais. São Paulo: EDUSP, 1999. $536 \mathrm{p}$.

MARTHA-ESTRADA, R. Hábitos alimentarios de los peces del genero Haemulon (Pisces: Haemulidae) de los arrecifes de la region de Santa Marta, Colombia. An. Inst. Investnes Mar., v. 15-16, p. 49 - 66, 1986.

MATHESON, R. E.; GILMORE, R. G. Mojarras (Pisces: Gerreidae) of the Indian River Lagoon. Bull. mar. Sci. v. 57, p. $281-282,1995$
MATSUURA, Y. Contribuição ao estudo da estrutura oceanográfica da região sudeste entre Cabo Frio (RJ) e Cabo de Santa Marta Grande (SC). Ciênc. Cult.,S Paulo, v. 38, p. 1439 -1450, 1986

MATSUURA, Y.; NAKATAMI, K. Ocorrência de larvas e jovens de peixes na Ilha Anchieta, com algumas anotações sobre a morfologia da castanha, Umbrina coróides. Bolm Inst. Oceanogr., S Paulo, v. 28, p. 165183, 1979.

MENEZES, N. A.; BUCKUP, P. A.; FIGUEIREDO, J. L.; MOURA, R. L. Catálogo das espécies de peixes marinhos do Brasil. São Paulo: Museu de Zoologia, USP; EDUSP, 2003. $160 \mathrm{p}$.

MICHALSEN, K.; GODO, O. R.; FERNE, A. Diel variation in the catchability of gadoids and its influence on the reliability of abundance indices. ICES J. mar. Sci., v. 53, p. $389-395,1996$.

MUTO, E. Y.; SOARES, L. S. H.; ROSSIWONGTSCHOWSKI, C. L. D. B. Demersal fish assemblages off São Sebastião, southeastern Brazil: structure and environmental conditioning factors (summer 1994). Rev. Bras. Oceanogr., v. 48, p. 9-27, 2000.

NOAKES, D. L. G. Behaviour and rhythms in fishes. In: ALI, M. A. (Ed.). Rhythms in fishes. New York: Plenum Press, 1992. 39-50 p.

NONATO, E. F.; AMARAL, A. C. Z.; FIGUEIREDO, Z. L. Contribuição ao conhecimento da fauna de peixes do litoral norte do estado de São Paulo. Bolm Inst. Oceanogr., v. 32, p. 143-152, 1983.

PESSANHA, A. L. M.; ARAÚJO, F. G. Spatial, temporal and diel variations of fish assemblages at two sandy beaches in the Sepetiba Bay, Rio de Janeiro, Brazil. Estuar. coast. Shelf. Sci., v. 57, p. 817-828, 2003.

PIHL, L.; WENNHAGE, H. Structure and diversity of fish assemblages on rocky and soft bottom shores on the Swedish west coast. J. Fish Biol., v. 61, p. 148-166, 2002.

PIRES-VANIN, A. M. S. A macrofauna bêntica da plataforma continental ao largo de Ubatuba, São Paulo, Brasil. Publção esp. Inst. Oceanogr., v. 10, p. 137 158, 1993.

RAO, C. R. A review of canonical coordinates and an alternative to correspondence analysis using Hellinger distance. Qüestió., v. 19, p. 23-63, 1995.

ROCHA, G.R.A.; ROSSI-WONGTSCHOWISKI, C.L.D.B. Demersal fish community on the inner shelf of Ubatuba. Rev. Bras. Oceanogr., v. 46, p. 93-109, 1998.

RODRIGUEZ-ROMERO, J.; ABITIA-CÁRDENAS, L. A.; GALVÁN-MAGAÑA, F.; CHAVES-RAMOS, H. Composition, abundancia y riqueza especifica de la ictiofauna de Bahia Conception, Baja Califórnia Sur, México. Ciências mar., v. 20, p. 321-350, 1994.

ROSSI-WONGTSCHOWSKI, C. L D. B; PAES, E. T. Padrões espaciais e temporais da comunidade de peixes demersais do litoral norte do estado de São Paulo Ubatuba, Brasil. Publção esp. Inst. Oceanogr., v. 10, p. 169-188, 1993.

SCHULZ, J.; MÖLLMANN, C.; HIRCHE, H. J. Vertical zonation of the zooplankton community in the Central Baltic Sea in relation to hydrographic stratification as revealed by multivariate discriminant function and canonical analysis. J. mar. Sys., v. 67, p. 47-58, 2007. 
SEDBERRY, G. R.,; CARTER, J. The Fish Community of a Shallow Tropical Lagoon in Belize, Central America. Estuaries, v. 16, p. 198-215, 1993.

SHEPARD, F. P. Nomenclature based on sand-silt-clay ratios. J. sediment. Petrol., v. 24, p. 151-158, 1954.

SOARES, L. S. H.; GASALLA, M. A.; RIOS, M. T. R.; ARRASA, M. V.; ROSSI- WONGTSCHOWSKI, C. L. D. B. Grupos tróficos de espécies dominantes de peixes demersais da plataforma continental interna de Ubatuba, Brasil. Publção esp. Inst. oceanogr., v. 10, p. 189-198, 1993.

SOGARD, S.M.; POWELL, G.V.N.; HOLMQUIST, J.G. Utilization by fishes of shallow, seagrass-covered banks in Florida Bay: 2. Diel and tidal patterns. Environ. Biol. Fishes, v. 24, n. 2, p. 81-92, 1989.

STONER, A.W. Diel variation in the catch of fishes and Penaeid shrimps in a tropical estuary. Estuar. Coast. Shelf. Sci., v. 33, p. 57-69, 1991

TUYA, F,; BOYRA, A.; SANCHEZ-JEREZ, P.; HAROUN, R.J. Multivariate analysis of the bentho-demersal ichthyofauna along soft bottoms of the Eastern Atlantic: comparison between unvegetated substrates, seagrass meadows and sandy bottoms beneath sea-cage fish farms. Mar. Biol., v. 147, p. 1229-1237, 2005.

VAZ, S.; CARPENTIER, A.; COPPIN, F. Eastern English Channel fish assemblages: measuring the structuring effect of habitats on distinct sub-communities. ICES J. mar. Sci., v. 64, p. 271-287, 2007.
VEGA-CENDEJAS, M. E., SANTILLANA, M. H., 2004. Fish community structure and dynamics in a coastal hypersaline lagoon: Rio Lagartos, Yucatan, México. Estuar. coast. Shelf. Sci., v. 60, p. 285 - 299.

WASHINGTON, H. G. Review: diversity, biotic and similarity indices. Water Res., v. 4, p. 337-403, 1984

WEINSTEIN, M. P.; WEISS, S. L.; WALTERS, M. F. Multiple determinants of community structure in shallow marsh habitats, Cape Fear River Estuary, North Carolina, USA. Mar. Biol., v. 58, p. 227-243, 1980

ZAHORCSAK, P,; SILVANO, R. A. M.; SAZIMA, I. Feeding biology of a guild of benthivorous fishes in a sandy shore on south-eastern Brazilian coast, Rev. Bras. Biol. v. 60, p. 511-518, 2000.

(Manuscript received 05 May 2009; revised 15 September 2009; accepted 03 November 2009) 